\title{
Western Mediations in Reevaluating the Communist Past: A Comparative Analysis of Gothár's Time Stands Still and Andonov's Yesterday
}

\author{
Roumiana Deltcheva \\ Montréal
}

Follow this and additional works at: https://docs.lib.purdue.edu/clcweb

C.

Part of the Comparative Literature Commons, and the Critical and Cultural Studies Commons

Dedicated to the dissemination of scholarly and professional information, Purdue University Press selects, develops, and distributes quality resources in several key subject areas for which its parent university is famous, including business, technology, health, veterinary medicine, and other selected disciplines in the humanities and sciences.

CLCWeb: Comparative Literature and Culture, the peer-reviewed, full-text, and open-access learned journal in the humanities and social sciences, publishes new scholarship following tenets of the discipline of comparative literature and the field of cultural studies designated as "comparative cultural studies." Publications in the journal are indexed in the Annual Bibliography of English Language and Literature (Chadwyck-Healey), the Arts and Humanities Citation Index (Thomson Reuters ISI), the Humanities Index (Wilson), Humanities International Complete (EBSCO), the International Bibliography of the Modern Language Association of America, and Scopus (Elsevier). The journal is affiliated with the Purdue University Press monograph series of Books in Comparative Cultural Studies. Contact: <clcweb@purdue.edu>

\section{Recommended Citation}

Deltcheva, Roumiana. "Western Mediations in Reevaluating the Communist Past: A Comparative Analysis of Gothár's Time Stands Still and Andonov's Yesterday." CLCWeb: Comparative Literature and Culture 1.4 (1999): <https://doi.org/ 10.7771/1481-4374.1057>

This text has been double-blind peer reviewed by $2+1$ experts in the field.

The above text, published by Purdue University Press @Purdue University, has been downloaded 776 times as of $11 /$ 07/19. Note: the download counts of the journal's material are since Issue 9.1 (March 2007), since the journal's format in pdf (instead of in html 1999-2007).

This document has been made available through Purdue e-Pubs, a service of the Purdue University Libraries. Please contact epubs@purdue.edu for additional information.

This is an Open Access journal. This means that it uses a funding model that does not charge readers or their institutions for access. Readers may freely read, download, copy, distribute, print, search, or link to the full texts of articles. This journal is covered under the CC BY-NC-ND license. 


\title{
PURDUE \\ UNIVERSITY PRESS < http://www.thepress. purdue.edu>
}

\section{CLCWeb: Comparative Literature and Culture}

ISSN 1481-4374 <http://docs.lib.purdue.edu/clcweb> Purdue University Press @Purdue University

CLCWeb: Comparative Literature and Culture, the peer-reviewed, full-text, and open-access learned journal in the humanities and social sciences, publishes new scholarship following tenets of the discipline of comparative literature and the field of cultural studies designated as "comparative cultural studies." In addition to the publication of articles, the journal publishes review articles of scholarly books and publishes research material in its Library Series. Publications in the journal are indexed in the Annual Bibliography of English Language and Literature (Chadwyck-Healey), the Arts and Humanities Citation Index (Thomson Reuters ISI), the Humanities Index (Wilson), Humanities International Complete (EBSCO), the International Bibliography of the Modern Language Association of America, and Scopus (Elsevier). The journal is affiliated with the Purdue University Press monograph series of Books in Comparative Cultural Studies. Contact: <clcweb@purdue.edu>

\author{
Volume 1 Issue 4 (December 1999) Article 7 \\ Roumiana Deltcheva, \\ "Western Mediations in Reevaluating the Communist Past: A Comparative Analysis of \\ Gothár's Time Stands Still and Andonov's Yesterday" \\ <http://docs.lib.purdue.edu/clcweb/vol1/iss4/7> \\ Contents of CLCWeb: Comparative Literature and Culture 1.4 (1999) \\ <http://docs.lib.purdue.edu/clcweb/vol1/iss4/>
}

Abstract: Roumiana Deltcheva's article, "Western Mediations in Reevaluating the Communist Past: A Comparative Analysis of Gothár's Time Stands Still and Andonov's Yesterday," offers a comparative analysis of two films, Peter Gothár's Time Stands Still and Ivan Andonov's Yesterday. Both films appeared in the 1980s, in Hungary and Bulgaria, respectively, and were highly acclaimed by the critics and the audience. Both films deal with the Communist past of these two countries. In her analysis, Deltcheva's adopts the perspective of "in-between peripherality," a particular manifestation of the post-colonial paradigm in its application to East Central and Central Europe. The two films use similar strategies to suggest the specific position that the countries belonging to the Soviet sphere of political influence possessed during the forty years of communist rule. Ironically, the films completed prior to the Changes of 1989 present a much more vivid representation of these processes than anything else that has since been produced in the region. 


\section{Roumiana DELTCHEVA}

\section{Western Mediations in Reevaluating the Communist Past: A Comparative Analysis of Gothár's Time Stands Still and Andonov's Yesterday}

The dramatic socio-political changes that took place in Central and East Central Europe at the beginning of the decade have led to the need of a methodological shift in approaching the culture of the region. From a socio-semiotic perspective, one of the implications of this shift and a direct consequence of the end of the Cold War is the transition from binarism towards a volumetric ternary structure. These are terms I borrow from Iurii Lotman as he develops them in his last book, Kul'tura $i$ vzryv (Culture and Explosion). Lotman claims that it is high time we overcome the inherently explosive paradigm of binary oppositions (either/or, black-and-white dichotomies) in favour of a more "constructive" ternary structure based on evolution, gradualness, and democracy. For Lotman, binarism and revolutionary destructiveness has been a traditional determinant of Russian history while the West has a well-established tradition in suppressing conflict in favour of gradual evolution and continuity. It is not my intention here to discuss Lotman's new model although I find it somewhat problematic insofar as it is based on a rather idealized perception of Western democracy. Nevertheless, I do find it useful to apply Lotman's notion of ternary structure in approaching Central and East Central European culture since the model opens up possibilities to integrate the region in European studies and at the same time to break down the erroneous Euro-homogenizing tendencies so common from the locus of observation in North American scholarship (for an example of my previous work on this topic, see Deltcheva <http://docs.lib.purdue.edu/clcweb/vol1/iss2/4/>).

The decade of post-communism has opened for us new themes and issues which need to be addressed that go beyond the rather simplistic formula of "us" versus "them." What I mean is that while the totalitarian regimes in the past to some extent validated a narrow ideologically-based definition of socialist art as epic, formulaic, and subjugated to the dominant political discourse, their demise in 1989 have created the need to reevaluate the recent past of Central Europe from diverse angles, and introduce concepts that will allow us to acknowledge and integrate the cultural processes occurring in the region into the theoretical domain of comparative cultural studies (for the notion of comparative cultural studies, see Tötösy 1999 <http://docs.lib.purdue.edu/clcweb/vol1/iss3/2/>). An important gesture to complement the process is for European culture and scholarship to turn towards Central and East Central Europe beyond the perspective of the "exotic." This opinion is promoted by Austrian filmmaker of Serbian descent Goran Rebic according to whom European cinema will be able to overcome the vicious circle of derivativeness and repetition if it turns towards the problematic of Central and East Central Europe (qtd. by Bratoeva).

One such broadening of the perspective towards Central and East Central Europe is furnished by post-colonial theory provided that we realize the peculiarities of the milieu. Thus, Central and East Central Europe can be viewed as a periphery of two sides: on the one hand, the West as a traditional cultural centre has unavoidably exerted strong influence on the East. On the other hand, there is a second centre of power which acts from the East, i.e., the former Soviet Union through the mechanism of a "filtered" colonialism "through ideological, political, social, cultural, and other means" (Tötösy 131). The situation is further complicated by the fact that the cultural influence of the West is not a post-Cold War development only but has been on-going for centuries with particular impetus since the nineteenthth century. Moreover, the conscious attempt on the part of Central and East Central Europe to emulate the West is not viewed as colonialism but as a process of integration, "the way to Europe." This ambiguous struggle validates Steven Tötösy's statement that "it is possible to speak, in and from North America, of a unified 'Eurocentrism,' when in Europe itself and from the locus of East Central Europe there is a marked centre/periphery situation within politics and economics as well as in culture and literature" (135). Totosy calls this peculiar geo-political and cultural disposition of Central Europe "in-between peripherality, a specific and mediating altérité" (136), a term that I have adopted in my own work. Similarly to Tötösy, in the dedication to his 1993 book, Borderline Culture, USA citizen Serbian Tomislav Longinovic writes the following: "For my daughters ... to remember those lands-in-between where their parents came from." It is hardly accidental that in spite of the new political status quo, it is exactly "those lands-in-between" that continue to undergo 
deep identity crises and are in a constant state of fluidity. In my discussion here, I want briefly to analyze and compare two Central European films from the 1980s, Péter Gothár's Time Stands Still (Megáll az idö) (1981) from Hungary and Ivan Andonov's Yesterday (Vchera) (1987) from Bulgaria. I will focus specifically on how these two cultures, geo-politically belonging to the Central and East Central Europe respectively, appropriate Western cultural artefacts and infuse them with political meanings directly counteracting the subjugating dominance of the political centre of power -- the USSR. In addition, I would like to suggest that these films can be granted a modified reading from the vantage point of our decade, the decade of the post-communist transitional period.

Both films appeared in the 1980s and were highly acclaimed both by critics and the audience. From the point of view of their plot structure, they possess similarities that merit a closer examination. Both films deal with the communist past of the two countries. Gothár focusses in particular on the aftermath of the 1956 Hungarian revolution and its psychological impact on those who were active in the uprising and those who chose to conform and later took charge of the system. Andonov's film is also oriented towards the past: however, it explores the subtler mechanisms of manipulation that the communist system effected on the lives of Bulgarians belonging to different social strata within a less "rebellious" context. Both films investigate the ravages of political abuse as they are reflected in the personal worlds of high school students representing the new generation with their hopes and their frustrations. The choice of adolescence as a painfully turbulent period juxtaposed to the stagnation in the public domain acquires additional ideological significance. The inherent ambiguity defining the totalitarian society is further reinforced by the cinematic incorporation of a whole set of Western cultural markers whose visual and aural presence subvert the dominating monological communist discourse. The overall result is an ambivalent look into history where nostalgia, bitterness, and a subdued hopefulness for the future converge. Already the titles of the two films evoke musical references and suggest that music is functionalized on the level of ideology and goes beyond its technical framing role. Gothár's film takes its title from a nostalgic Hungarian tune associated with the 1956 revolution. The actual song appears in the film as the musical backdrop for the older generation and accentuates the loss of their illusions. Andonov's title is more transparent for the non-Bulgarian since it invokes one of the Beatles' most popular songs. Once again, the dominant mood is that of nostalgia and frustration with the lost battle against conformity and stagnation. Both films deal with failure: failure in opposing an oppressive system and in achieving personal fulfillment. In terms of its temporal parameters, Time Stands Still possesses a more epic quality in that it spans over a period of eleven years, from November 1956 until December 1967. Compositionally, it consists of three segments: a pre-credit opening sequence in black and white, where factual and fictional images from Budapest merge to document a failed revolution. The sequence ends with a freeze-frame of a mother and two sons behind a window watching the husband/father fleeing the country. The image serves as the transition for the second, longest sequence which takes place seven years later. Slowly, the frozen faces come to life and the screen is infused with colour. The narrative follows the lives of the two brothers, Dénes (István Znamenák) and Gábor (Henrik Pauer), in an apathetic society where everything is subordinated to anonymous directives and empty rhetoric. Much of the action takes place "in the echoing, restrictive corridors of Dénes's school, dramatically representative in little of the Hungarian society at large which holds oppressive sway outside its gates" (Burns 189). It is here that the ideological clashes between different values and beliefs take place. The epilogue establishes the third time reference in the film. It is set in 1967 and consists of three short sequences that provide some closure regarding the fates of the various protagonists.

According to Marek Haltof and Donald Smith, the characters in the film can be viewed as "representatives of differing ideological positions in Hungarian society and as embodying possibilities for resolving the historical crisis of 1956 vis à vis the present and the future" (53). Éva (Ági Kakassy), Laci (Lajos Öze), and Pista (Tamás Jordán) are the common citizens who support the anti-Stalinist revolution and later have to pay for their audacity. Éva, Dénes and Gábor's mother, succinctly explains her position to Lívia (Mária Ronyecz), her son's teacher who despite her open-mindedness remains a member of the communist system: "You are where you are on your side. I am where I am on mine. I never bothered about you people. Your husband was being shot at by my husband." Laci and Pista represent the two possible paths for the insurgents. Pista, Éva's husband, escapes to the West and is seen as a homogeneous concept for we never learn exactly where he is. His friend, Laci, is caught and 
serves time in prison. Later, he moves in with Éva, becomes a surrogate father to the boys, and does his best to adapt to the new circumstances. There are three characters on the communist side, as well -- Lívia, Szombati (Jozef Kroner), and Rajnák (Pál Hetényi). Lívia replaces Szombati as a teacher of Russian at the school. While Szombati is presumably portrayed in a positive light as the sole bearer of religious and spiritual values, his traditionalist approach to sexuality as a means for procreation implicitly marginalizes him and exposes the limitations of his worldview. Lívia, on the other hand, represents a more modern set of values expressing a critical stand towards the hypocrisy of the establishment. This idea is reinforced by the motto she abides by, a quote by the Hungarian poet József Attila we see on a poster in the film: "We are humans, not beasts. We have minds and as long as our hearts nourish desire, we are not data for filing systems." Her overall conduct at school quickly makes her into an idol for the students. Yet, Lívia's personal life is as sterile as the public stratum she belongs to: she is childless and her husband is psychologically unstable, as a result of which she must literally keep him locked up. We never learn the actual reasons for his breakdown but there are hints that his personal life has been destroyed by political compromise.

The students in the film express the nihilistic rebellion of the young generation towards their parents' past. Their lives are removed from the immediate consequences of the 1956 revolution. To them, the hypocrisy and hollowness of the subsequent regime is equally incapable of providing a meaningful existence. Politics and history are transformed into empty concepts that become a target for mockery. As an alternative, they crave for pornographic photographs from Western magazines because they are "better than Hungarian youth magazines" (a wonderful parallel of the same is found in Thomas Brussig's award-winning 1996 novel about East German life in Berlin, Helden wie wir). Throughout the film, Western music -- mainly American rock hits such as "You Are My Destiny," "Don't Be Cruel," and "Tutti Frutti"-- dominates the coming-of-age scenes of the young generation. Vilma (a surname here; Péter Gálfi), the son of a highly positioned communist functionary, becomes the vehicle by which other material artefacts of the Western cultural centre are introduced into the film: after a trip to London, his parents bring him a tape recorder, Philip Morris cigarettes, and large bottles of Coca Cola, the drink with magic and desiredly decadent properties. The ideological significance of the garishly material presence of the West is rendered visually in the scene of the party at Lívia's house, that is, the "communist den," where even the blaring music cannot entirely drown the nonsensical babble of a regime devoid of any credible essence.

Throughout the film, the protagonist Dénes retains an attitude of reluctance and passive resistance towards the system. On the other hand, his classmate Pierre (Sándor Tóth) can be viewed as "the quintessential nihilist" (Haltof and Smith 57). He is the one who incites his classmates towards active rebellion culminating in an act of vandalism: a group of frenzied students destroy the portraits of Hungarian and international communist leaders hanging in the school hallways. Pierre -- and his nonHungarian name is ideologically significant -- is the only one who actively seeks ways to physically escape his reality by pursuing the American dream. He organizes a clandestine operation to cross the Hungarian border into Austria. Initially, he invites Gábor to join him, but the latter pulls out because he realizes that he has a chance to integrate himself in the Hungarian academic establishment. Dénes seems keen to go with him, but in the end also chickens out and returns to Budapest with his school sweetheart. Pierre goes alone.

Throughout the film there is an explicit connection between politics and sex (for an example of this quintessential element of Central European culture under communist rule, see Tötösy 1996). Conceptually, the two themes belong respectively to the public and the personal domains. Yet, they receive a similar treatment -- one of detachment and intentional carnivalization. In this context, it is worth observing that the presence of the West is promoted on the level of sexual politics, as well. There is an implicit suggestion in the film of a possible homosexual relationship between Pierre and Vilma, the two characters who bear the closest connection to the West. According to Haltof and Smith, "Within the context of a film in which opposite gender relations are fraught with tension and conflict (and in which camaraderie among men is presented as an idealized almost romantic alternative), the subtle suggestion that Vilma's sexual orientation might be at least latently homosexual adds a very interesting counterpoint and a more inclusive representation to this poignant portrait of an emotionally troubled generation" (61). I would add that this tendency is even more obvious with Pierre, who asks Dénes to give him a kiss before his defection. 
The second sequence ends with Dénes's aborted attempt to cross the border. Without anything really being resolved, there is a fastforward to the New Year's eve of 1968 and a superficially imposed carnivalized closure trying to cover up a much more disturbing spiritual cul-de-sac. By some kind of magical intervention, Lívia is shown in a maternity ward with a newborn baby and a grateful, psychologically recovered husband kneeling in front of her. Éva and Laci are happily reunited with an obviously prosperous Pista in an ambiguous ménage-à-trois. A brief shot shows us Gábor in a lab achieving break-through scientific results with his guinea pigs. Another character, Dini, who four years ago gave up defection in order to remain with his beloved Magda (Anikó Iván), is shown walking alone on the street, drunk in a soldier's uniform. He stops to urinate, oblivious of his surroundings. At that same moment, the camera captures a presumably drunk Magda walking on the opposite side of the street, with another man by her side, pushing a baby carriage. The film ends with a shot of Magda frivolously saluting Dini from afar with a toy horn. The overall comic quality of the epilogue acquires a much more sinister characteristic as soon as we infuse it with a political dimension. The drunken stupour of the New Year celebration highlight even more poignantly the tragic events following the Soviet-led intervention in Czechoslovakia in 1968 by Warsaw Pact troops where there was Hungarian military participation. According to Burns, Time Stands Still is a film about failure where "authority proves weak and great hopes are not realized; it ends in a monochrome, in an empty street where we have seen a drunk relieving himself and a former girlfriend passing him by. Finally, Dénes is merely a nice boy who made nothing of himself" (190). I would add another pessimistic note. Not only does Dénes passively resign himself to the flow, but the symbolic implication of his uniform is that he will be actively involved in the repressive actions against the Prague Spring. In this sense, Gothár's film is as much about failure as it is about betrayal: betrayal both in the personal -- love and ideals -- and the public domain. In the end, old and young give in and accept the system.

It is the theme of betrayal that directly establishes the kinship between Time Stands Still and Ivan Andonov's Yesterday. In addition to the common symbolic locus chosen by the two directors -- the school as a microcosm of totalitarian society -- the two films artistically sustain a common visual poetics. The Bulgarian film spans a much shorter period -- one term in the schoolyear of senior pupils in an elite English-language high school, taking place in the late 1960s when the Beatles have become the idols of the Western world and the sexual revolution is at its heyday. The presence of the liberating wind from the West is felt from the very first scenes and underscores the entire film. While Gothár's film subtly juxtaposes Paul Anka and Elvis Priestly to Hungarian popular tunes and nostalgic romances, Andonov emphasizes a single musical reference: the Beatles. The film is interspersed with bits of dialogue in English: from Shakespeare quotations to song lyrics and a quaint exchange between students and teachers in a mixture of Bulgarian and English. The participation of Christine Bartlett in the film, a real-life teacher from the UK, leaves no doubts as to the director's intentions to highlight the very tangible presence of the Western cultural tradition in all its variations: besides rock and pop music, there are a number of literary references to Shakespeare's Macbeth, Hamlet, King Lear, J.D. Salinger's The Catcher in the Rye, Bertold Brecht's théâtre engagé, as well as the geographical spaces of England and Sweden. The material signifiers of the West, similarly to Time Stands Still, are Kent cigarettes, LPs, and posters of the Beatles. In one scene, significantly, the posters are publicly destroyed by the math teacher Barakov (Nikola Rudarov), one of the most narrow-minded and evil characters in the film and who is also an informant for the police. He is the counterpart to the assistant principal Rajnák in Gothár's film, the ultimate product of the system and a truly menacing character.

The main protagonist of Yesterday, Ivan (Khristo Shopov) closely resembles Dini. Like him, he is stubborn, proud, and independent. Unlike Dini, however, Ivan's starting conditions are much better: he is the son of the editor-in-chief of an important newspaper and hence he is allowed the luxury of playing small pranks without graver consequences than a reprimand from the principal. All this changes once his father is removed from his position. The father's fall from grace immediately reflects on Ivan who becomes a target for abuse not only for the math teacher but also for a ubiquitous inspector from the ministry who seems to know -- much more than the principal -- every little detail about what is going on in the boarding school. Ivan's non-conformist nature is highlighted when he is selected to play the role of Holden Caulfield by an eccentric yet open-minded theatre director who advocates individual freedom as the ultimate virtue. Among the various other protagonists the one 
who emerges as both Ivan's alter ego and his nemesis is Roco (Gueorgui Staikov), the only student who comes from an underprivileged background. "Unlike all of you who landed in this school with the help of parachutes, I had to work hard to deserve my place her," claims Roco. Very sensitive to the class stratification within socialist society, Roco becomes the proponent of extreme, amoral Darwinism: he cares for no one and serves no one; what matters is that he himself succeeds. His views are tainted by a bitter cynicism expressed in the words: "Best friends betray the best." Ironically, in his arrogant assurance that his radical individualism will become a vehicle to his successful integration into the system, Roco drowns before the eyes of his friend, desperately trying to prove that he can "swim against the current." Unfortunately, he is tragically wrong.

Paradoxically, Yesterday depicts one of the most dramatic periods in modern Bulgarian history both as a nostalgic "bubble" of a frozen moment of the times of stagnation and as an optimistic belief in the unlimited potential of youth. While the privileged background of the students suggests their belonging to the communist ruling class by default, their subversive gestures of nihilism and rebellion and their refusal to become betrayers in spite of their indoctrination on a daily basis -- mediated by constant cultural and material references to the Western and in the context democratic tradition -- point to a more complex and ambivalent interpretation of the recent past. In this sense, the collective scene where the classmates pronounce their oath of allegiance to one another under the musical accompaniment of the Bulgarian group the Crickets (a Bulgarian version of the Beatles) foregrounds an optimistic vision that the future generations just might be able to succeed where the parents failed. And yet, like in Gothár's film, pessimism seems to overwhelm all other sentiments. The oath of allegiance sequence cedes to the last film sequence depicting Ivan desperately swimming in the same stream where Roco drowned. When he reaches the entrance of the tunnel leading to the rapids, his swim in the river of life is drastically cut short by a protective grid put in to prevent any other unfortunate accidents. The film ends with Ivan's helpless cry: "Let me go! I am alive." No one hears him.

Both films treat similar problematics in the particular circumstances of two varieties of the socialist reality. In conclusion, I focus on aspects directly pertaining to the notion of in-between peripherality I presented in my introduction. As artistic products of Hungarian and Bulgarian socialist art, the films are significant because they unequivocally reject the rather simplistic premise that under the Soviet political domination cross-cultural dialogism was completely obliterated by dogmatic formulas and schematism. In fact, the films demonstrate that at the times of acute political repression, the Western cultural centre is activated to act as a politically subversive mechanism. Every instance of appropriation of a cultural artefact from the West European and North American semiosphere -- music, literature, pop culture -- acquires a symbolic significance beyond its merely decorative function and highlights even more the oscillation between the cultures of Central and East Central Europe and the West leading to a paradoxical legitimation of the "Europeanness" of the countries in-between. In the case of countries such as Hungary and Bulgaria, this legitimation is equally relevant for their own identity construction as it is for their recognition by the Western centre. It leads to at least a partial dispersion of the exoticizing tendencies that the West has traditionally manifested towards these two "obscure" cultures: towards Hungary owing to its non-Indo-European roots and language and historical situation between the Slavs and the West and towards Bulgaria owing to its Balkanic singularity, acquired Slavicism, and inconsequential geo-political status (for an example, see Deltcheva <http://docs.lib.purdue.edu/clcweb/vol1/iss2/4/>).

I finish my analysis by suggesting that with the political changes that took place at the end of the 1980 s, new readings of the issues raised in the two films become possible. From the vantage point of the moment when they were produced, the nostalgic overtones of the past merge with the idealistic expectations for the future via the mediation of the Western cultural presence which is, generally speaking, positively valorized. In the context of the present, however, after bearing witness to the painful transitional period and the loss of all values in the course of fierce struggle for mere existence as well as a new kind of in-between and peripheral situation based this time on economic problems rather than political animosity, the regenerative powers of the Western centre become much more questionable. Obviously, more in-depth comparative work is needed -- for many reasons -- about these and other issues regarding Central and East European culture. 


\section{Works Cited}

Andonov, Ivan. Yesterday. Sofia: National Film Centre and Magic Film, n.d.

Bratoeva, Ingeborg. "Gorchivite predimstva na malkoto kino" ("The Bitter Advantages of Small-Scale Cinemas"). Kultura (12 February 1999): 8.

Brussig, Thomas. Helden wie wir. Berlin: Volk und Welt, 1996.

Burns, Bryan. World Cinema: Hungary. Madison: Farleigh Dickinson, 1996.

Deltcheva, Roumiana."East Central Europe as a Politically Correct Scapegoat: The Case of Bulgaria." CLCWeb: Comparative Literature and Culture 1.2 (1999): <http://docs.lib.purdue.edu/clcweb/vol1/iss2/4/>.

Gothár, Péter. Time Stands Still. New York: RCA/Columbia Pictures Home Video, 1986.

Haltof, Marek, and Donald Smith. "An Aborted Revolution, a Stillborn Generation: Generational Politics and Gender Relations in Péter Gothár's Time Stands Still." Canadian Journal of Film Studies 6.2 (1997): 51-64.

Longinovic, Tomislav Z. Borderline Culture: The Politics of Identity in Four Twentieth-Century Slavic Novels. Fayetteville: U of Arkansas P, 1993.

Lotman, Iurii. Kul'tura i vzryv (Culture and Explosion). Moskva: Gnozis, 1992.

Tötösy de Zepetnek, Steven. "Political Satire in Hungarian Exile Literature: Systemic Considerations." The Search for a New Alphabet: Literary Studies in a Changing World. Ed. Harald Hendrix, Joost Kloek, Sophie Levie, and Will van Peer. Amsterdam: John Benjamins, 1996. 250-55.

Tötösy de Zepetnek, Steven. Comparative Literature: Theory, Method, Application. Amsterdam: Rodopi, 1998.

Tötösy de Zepetnek, Steven. "From Comparative Literature Today toward Comparative Cultural Studies." CLCWeb: Comparative Literature and Culture 1.3 (1999):

<http://docs.lib.purdue.edu/clcweb/vol1/iss3/2/>.

Author's profile: Roumiana Deltcheva's interests in scholarship include comparative literature, Central and East Central European literature and culture, film-literature relations, media studies, and identity politics and post-colonial issues. She has published articles in the Canadian Review of Comparative Literature/Revue Canadienne de Littérature Comparée, Studies in the Humanities, The Russian Review, Europe-Asia Studies, The Sarmatian Review, and others, and co-edited Literature and Film: Models of Adaptation, a special issue of the Canadian Review of Comparative Literature/Revue Canadienne de Littérature Comparée. Deltcheva serves on the advisory board of CLCWeb and she has previously published "East Central Europe as a Politically Correct Scapegoat: The Case of Bulgaria" in CLCWeb: Comparative Literature and Culture 1.2 (1999): <http://docs.lib.purdue.edu/clcweb/vol1/iss2/4/>. Deltcheva works in new media technology and business and lives in Montréal. E-mail:

<rdeltche@yahoo.com>. 